\title{
„Duch, który przekonywa świat o grzechu” (DeV 27). Pneumatologiczna reinterpretacja profetyczno-krytycznej misji Kościoła w świecie
}

\author{
"The Spirit who convinces the world of $\sin$ ( DeV 27). The Pneumatological \\ Reinterpretation of the Prophetic and Critical Mission of the Church in the World
}

\section{JERZY GOCKO}

Katolicki Uniwersytet Lubelski Jana Pawła II

Jerzy@Gocko.pl, ORCID ID: 0000-0002-6513-5681

\begin{abstract}
Streszczenie: Celem artykułu jest zwrócenie uwagi na rolę Ducha Świętego w posłannictwie Kościoła w świecie. Duch Święty nie tylko wskazuje konkretne kierunki i środki tego posłannictwa, ale jest nade wszystko źródłem tego posłannictwa, a więc także źródłem jego owocności (1). Duch Święty jako ożywcza moc i światło napotyka jednak w tym świecie na opór i sprzeciw, w pierwszej kolejności w wymiarze wewnętrznym i podmiotowym poprzez grzech, a następnie w zobiektywizowanym kształcie kultury i cywilizacji, co we współczesnej teologii znalazło wyraz w koncepcji „grzechu społecznego" i „struktur grzechu" (2). Jeśli Kościół chce rozpoznać i urzeczywistnić swoją posługę wobec świata wedle mandatu otrzymanego od Chrystusa, musi ciągle otwierać się na Ducha Świętego, który „przekonuje świat o grzechu, sprawiedliwości i sądzie" (J 16,8). Dziś to zadanie przekonywania świata o grzechu podejmuje Kościół przede wszystkim na płaszczyźnie doktrynalnej. W odniesieniu do sfery społecznej rolę tę pełni nauka społeczna Kościoła poprzez swój profetyczno-krytyczny wymiar (3).
\end{abstract}

Słowa kluczowe: Duch Święty; Kościół; posłannictwo Kościoła w świecie; encyklika Dominum et Vivificantem; nauka społeczna Kościoła; grzech; grzech społeczny

Abstract: The paper is aimed at highlighting the role of the Holy Spirit in the mission of the Church in the world. (1) Besides indicating the specific directions and means of this mission, the Holy Spirit is, first and foremost, its source and consequently the source of its fruitfulness. (2) In this world, however, the Holy Spirit, as the invigorating power and light, encounters resistance and opposition, first in the internal and subjective dimension through sin, and then in the objectified shape of culture and civilization, which in modern theology found its expression in the concept of "social sin" and "structures of sin". (3) If the Church wants to recognize and realize its ministry to the world according to the mandate received from Christ, it must be constantly open to the Holy Spirit, who "convinces the world of sin, justice and judgment" (Jn 16: 8). Today, the task of convincing the world of sin is undertaken by the Church primarily on the doctrinal level. In relation to the social sphere, this role is played by the Church's social teaching through its prophetic and critical dimension.

Keywords: The Holy Spirit; the Church; the mission of the Church in the world; the encyclical letter Dominum et Vivificantem; social teaching of the Church; sin; social sin 
Dzieje Kościoła nie urzeczywistniają się gdzieś na obrzeżach historii świata i ludzkości czy poza nią. Wręcz przeciwnie. Dlatego podejmowana nieustannie przez teologię próba zrozumienia i opisania charakteru obecności i posłannictwa Kościoła w świecie musi być zawsze konsekwencją szerszego procesu przemian w obrębie całej teologii oraz szeregu innych czynników ją determinujących. Ostatnie stulecie, a zwłaszcza wydarzenie Soboru Watykańskiego II, obejmujące zarówno proces dojrzewania głównych idei soborowych, jak również ich recepcji, było czasem szczególnym, w którym nastąpiła znaczna zmiana optyki w spojrzeniu na relację Kościoła i świata i dokonało się doniosłe jej pogłębienie. W trzech doktrynalnych konstytucjach soboru: Dei verbum, Lumen gentium i Gaudium et spes, znalazła uwieńczenie teologia bardziej wrażliwa na ekonomię zbawienia niż na abstrakcyjne studium dogmatycznych aspektów wiary. Sobór potwierdził i uprawomocnił nowy sposób uprawiania teologii, wypracowywany od lat trzydziestych ubiegłego wieku, zwłaszcza we Francji, który chciał potraktować z powagą wszystkie konsekwencje idei Objawienia chrześcijańskiego, rozumianego jako historia zbawienia, a nie jedynie jako katalog prawd objawionych.

Ujęcie teologii jako refleksji nad historią zbawienia oznacza, że nie można wypracowywać koncepcji teologicznych bez odniesienia się do współczesnego świata, aktualnych wydarzeń, bez zaangażowania w dzieje człowieka, bez obecności w jego aspiracjach i strukturach życia społecznego, które tworzy. Współczesne dzieje świata i człowieka są miejscem stałej inwencji i stałego rodzenia się teologii ${ }^{1}$. W nurcie takiej teologii należy umieścić wszelkie próby poszukiwania ważnych kategorii teologicznych, które będą pomocne w zrozumieniu obecności i posłannictwa Kościoła w świecie.

Celem niniejszej naukowej refleksji jest zwrócenie uwagi na rolę Ducha Świętego w misji Kościoła wobec świata i to zarówno w wymiarze sprawczym, jak również w odniesieniu do konkretnych przejawów i form owego posłannictwa: to Duch Święty nie tylko wskazuje konkretne kierunki i środki tego posłannictwa, ale jest nade wszystko jego źródłem, a więc także źródłem jego owocności (1). Duch Święty jako ożywcza moc i światło napotyka jednak w tym świecie na opór i sprzeciw, w pierwszej kolejności w wymiarze wewnętrznym i podmiotowym poprzez grzech, a następnie w zobiektywizowanym kształcie kultury i cywilizacji, co we współczesnej teologii znalazło wyraz w koncepcji "grzechu społecznego" i „struktur grzechu” (2). Jeśli Kościół chce rozpoznać i urzeczywistnić swoją posługę wobec świata wedle mandatu otrzymanego od Chrystusa, musi ciągle otwierać się na Ducha Świętego, który jest nie tylko jego życiodajną zasadą i który prowadzi go przez ludzkie dzieje ku ostatecznemu spełnieniu, ale także tym, który „przekonuje świat o grzechu, sprawiedliwości i sądzie” (J 16,8). Dziś to zadanie przekonywania świata o grzechu podejmuje Kościół przede wszystkim na płaszczyźnie doktrynalnej. W odniesieniu do sfery społecznej rolę tę pełni nauka społeczna Kościoła poprzez swój profetyczno-krytyczny wymiar (3).

1 Chenu, Un théologien en liberté, 124-125. 


\section{Inkarnacyjno-pneumatologiczny fundament obecności Kościoła w świecie}

Historia Kościoła jako wspólnoty zbawienia objawia się w historii, dzięki historii i z historii, choć ją wewnętrznie przekracza w zakresie empirycznym. To szczególne uwyraźnienie świadomości historycznej Kościoła, której początkiem jest „wkroczenie Boga w historię", jest zasługą Soboru Watykańskiego $\mathrm{II}^{2}$. Oba wymiary Kościoła doczesny i eschatologiczny - łączą się najpełniej i wzajemnie przenikają w tajemnicy Wcielenia Jezusa Chrystusa, który jest ośrodkiem i źródłem łączności pielgrzymującego Kościoła ze światem. Stąd historiozbawczy charakter obecności i posłannictwa Kościoła w świecie oraz jego świadomość historyczna są ściśle zespolone zarówno ze świadomością stworzenia, jak i odkupienia kontynuowanego w „czasie Kościoła” przez Ducha Świętego.

Wcielenie to wejście Boga w czas i historię. Bóg objawiający się w Jezusie z Nazaretu wkroczył w los człowieka i przyjmując w sobie całą rzeczywistość ludzkiego uwarunkowania, odsłonił człowiekowi prawdę o nim samym oraz pełny sens ziemskiego świata. Słowo przyjęło ludzką naturę po to, aby podnieść wszystko, co istnieje w człowieku, ponieważ cały człowiek został przez Nie odkupiony i przebóstwiony. Dlatego to ekonomia inkarnacji, pogłębiona $z$ jednej strony przez nauczanie Soboru Watykańskiego II, z drugiej zaś przez takich prekursorów teologii rzeczywistości ziemskich, jak: Pierre Teilhard de Chardin, Gustave Thils, a zwłaszcza Marie-Dominique Chenu, jawi się jako niezwykle interesujący obszar poszukiwania teologicznych podstaw dla obecności i posłannictwa Kościoła w świecie.

Różnego rodzaju tendencje, zmierzające do teologicznego (w przeciwieństwie do socjologicznego i jurydycznego) ujęcia natury Kościoła, dostrzegają w tajemnicy Wcielenia prawzór dla dwuwymiarowego modelu Kościoła. Interesuje je przede wszystkim struktura Kościoła w ujęciu ontyczno-transcendentnym, w zestawieniu z unią hipostatyczną, jaka dokonała się przez Wcielenie Syna Bożego w Chrystusie Jezusie. Kościól jest nie tylko odbiciem prawzoru, jakim jest Chrystus, ale w swej bosko-ludzkiej strukturze pozostaje nadal incarnatio continua, analogicznie do Wcielenia. Określenie incarnatio continua należy tu rozumieć w sensie personalistycznym, a nie rzeczowym, tzn. że Chrystus, wcielając się w Kościół, w jego strukturze działa i prowadzi dalej swoje dzieło zbawcze osobiście, a nie zastępczo - przez ukonstytuowaną przez siebie instytucję zbawczą, jak to rozumiano w społeczno-prawnych ujęciach Kościoła ${ }^{3}$.

Momentem kluczowym wydaje się tutaj konstytuujący i opisujący wspólnotę Kościoła wymiar wertykalny, w którym to rozumiana jest ona w relacji do Chrystusa uwielbionego, a więc w aspekcie wewnętrznym. Jeżeli jeszcze w eklezjologii tradycyj-

Gocko, „Historyczność jako wewnętrzna zasada”, 377-384.

Łukaszyk, „Teologiczne spojrzenie na Kościół”, 5-10. 
nej relację tę ujmowano zasadniczo od strony genetycznej, widziano bowiem Kościół jako społeczność założoną przez Chrystusa celem kontynuacji Jego zbawczego posłannictwa, realizującą swoje zadania według wskazań, a także mocą Chrystusa historycznego, który wyposażył go w odpowiednie władze nauczania, uświęcania i pasterzowania, to obecnie mówi się o powtórnym wcieleniu Chrystusa we wspólnotę Kościoła. Dzięki temu drugiemu Wcieleniu w naturę społeczną Kościoła (pierwsze Wcielenie to wejście Syna Bożego w indywidualną naturę ludzką Chrystusa) prowadzi On nadal osobiście dzieło zbawienia jako Chrystus uwielbiony, na co wskazuje zapewnienie „a oto ja jestem z wami po wszystkie dni aż do skończenia świata” (Mt 28, 20). Jest to więc obecność nie w formie asystencji - bo wtedy Kościół, jako Lud Boży Nowego Przymierza, nie różniłby się w niczym od Ludu Bożego Starego Przymierza - ale faktyczne Wcielenie, dzięki któremu wspólnota Kościoła uniwersalnego jest Chrystusem dalej żyjącym, jak określa to teologia niemiecka (fortlebender Christus). Chenu w tym kontekście zwykł nazywać Kościół Ciałem Chrystusa, wcielonym i włączonym w ludzkość 4 , a wspólnotę Kościoła rozumiał on jako formę historycznej łaski, „Chrystusem w czasie", mającym ciało, którym jest sama ludzkość w historii ${ }^{5}$.

To poszukiwanie teologicznego fundamentu dla obecności i posłannictwa Kościoła w świecie w ekonomii inkarnacji, a właściwie - używając wyrażenia Yvesa Congara - w nowej ekonomii, czyli ekonomii obietnic spełnionych w postaci Wcielenia Syna i daru Ducha Świętego, nie może pominąć niezwykłej roli Ducha Parakleta w dziejach zbawienia. Kościół - odwołując się raz jeszcze do terminologii Congara - jest owocem dwóch misji Bożych, a mianowicie posłannictwa Syna i Ducha, zaś działanie Ducha Świętego w Kościele zmierza do budowania Ciała Chrystusowego, a więc i Ludu Bożego $0^{6}$. Duch Święty jest więc Tym, który urzeczywistnia działanie Syna w czasie dokonywania się dziejów zbawienia. To właśnie Jego mocą dokonuje się dzieło Wcielenia. Zesłanie Ducha Świętego stoi u początków Kościoła, a świadomość Jego posiadania stanowi dominujący czynnik w przeżyciach pierwszej wspólnoty eklezjalnej w Jerozolimie. Była ona świadoma, że Chrystus jest Mesjaszem, że dokonał zbawienia, bo zesłał na swój lud zapowiedzianego przez proroków Ducha (por. Iz 44,3). Jego mocą dokonało się i nadal się dokonuje głoszenie Ewangelii, rozszerzanie się Kościoła. Skutkiem, a zarazem widomym znakiem tego bezpośredniego działania Ducha Świętego na Kościół jako Lud Boży, są charyzmaty.

Jest rzeczą znamienną, że owa pneumatologiczna refleksja umiejscowiona jest w szerszym kontekście chrystologicznym oraz eklezjologicznym. Znaczącą rolę na tym obszarze poszukiwań teologicznych odegrał Congar, który podjął się zadania pogłębienia wymiaru trynitarnego i pneumatologicznego w eklezjologii. Jednak już

\footnotetext{
„L'Église, corps du Christ, incarnée, incorporée en humanitê" (Chenu, La Parole de Dieu, 352).

Chenu, Un théologien en liberté, 161.

Congar, Kościót, jaki kocham, 36.

Problematyka ta została zawarta przede wszystkim w trylogii Congara Wierzę w Ducha Świętego oraz w książce Duch człowieka, Duch Boga.
} 
encyklika Mystici Corporis, podejmując na nowo teksty św. Augustyna, rozwinęła naukę o Duchu Świętym jako „duszy” eklezjalnego Ciała Chrystusa, podkreślając w ten sposób więź łączącą Zesłanie Ducha Świętego z wydarzeniem Krzyża, a więc moment pneumatologiczny z momentem chrystologicznym ${ }^{8}$. Duch Święty jest osobiście dany uczniom i zamieszkuje w nich, a równocześnie jest dany Kościołowi jako jego życiodajna zasada9.

To Duch Święty jest Duchem Chrystusa i dopełnia Jego dzieło - budowanie Ciała Chrystusa, czyli Kościoła. Jemu też przypada rola animowania życia i posłannictwa Kościoła w ciągle aktualizującej perspektywie. To dzięki Duchowi Świętemu Kościół ustawicznie staje się nowym wydarzeniem. Eklezjologia pneumatologiczna Soboru Watykańskiego II nawiązuje więc do trynitarnej wizji ekonomii stworzenia i łaski, dotykającej trzech momentów: postanowienia Ojca, posłania Syna i misji Ducha Świętego. Analogicznie Kościół jest ludem Bożym, Ciałem Chrystusa oraz świątynią Ducha Świętego ${ }^{10}$.

Szczególnym impulsem doktrynalnym do pogłębienia badań nad pneumatologicznym fundamentem posłannictwa Kościoła w świecie była encyklika Jana Pawła II Dominum et Vivificantem o Duchu Świętym w życiu Kościoła i świata ${ }^{11}$. Jej celem było nie tyle pełne zgłębienie nauki o Duchu Świętym czy rozstrzygnięcie wszystkich kwestii spornych, ale wzrost świadomości Kościoła, że to „Duch Święty [...] przynagla go do współdziałania, aby spełnił się skutecznie zamysł Boga, który uczynił Chrystusa źródłem zbawienia dla całego świata". Sam autor postrzega ją jako odpowiedź na głębokie pragnienia ludzi współczesnych, które wyrażają się w „potrzebie nowego odkrycia Boga w Jego nadprzyrodzonej rzeczywistości Ducha Nieskończonego", potrzebie oddawania Mu czci „w Duchu i prawdzie”, „nadziei znalezienia w Nim tajemnicy miłości i siły nowego stworzenia" (DeV 2). Odpowiedzi tej udziela papież, czerpiąc z bogactwa dziedzictwa Vaticanum II, a zarazem podążając szlakiem ewangelicznym, patrystycznym i liturgicznym ${ }^{12}$.

Duch Święty ukazany został nie tyle od strony Jego istoty, co z perspektywy historii zbawienia, która zrodziła się w zamyśle Ojca; Chrystus jest jej definitywnym i trwałym centrum, a Duch ją prowadzi do spełnienia. Trynitarna niejako podstawa

8 W teologii, w nawiązaniu do Ewangelii św. Jana (por. 7,37-39), od czasów patrystycznych naucza się o podwójnym zesłaniu Ducha Świętego na Kościół: zesłaniu niewidzialnym na Krzyżu i widzialnym w dniu Zielonych Świąt. Przez swą śmierć i chwalebne zmartwychwstanie Chrystus wysłużył Kościołowi wszystkie łaski, a więc nie tylko łaski stworzone, ale również źródło wszelkich łask, czyli Ducha Świętego Boże principium życia. Wydarzenie to jest pierwszym momentem aspektu pneumatologicznego i stało się częścią składową misterium paschalnego. Do perspektywy tej wielokrotnie nawiązuje Pius XII w encyklice Mystici Corporis. Por. Congar, Kościót, jaki kocham, 33.

9 Por. Szwarc, „Duch Święty”, 31-49.

10 Congar, Les implications christologiques, 129-130; Czaja, Credo in Spiritum Vivificantem, 59-67.

11 Kontekst teologiczny dokumentu, jego genezę oraz aspekty metodologiczne i dogmatyczne szeroko omawia Krzemiński, „Encyklika Dominum et Vivificantem”, 129-148.

12 Świątek, „Pneumatologiczna interpretacja”, 1077-1086. 
chrystologii i pneumatologii każe postrzegać dzieło zbawcze jako dzieło zarówno Syna, jak i Ducha. Przez nie Chrystus dokonał obiektywnego odkupienia, ale uczynił to jako „pełen Ducha”. To Duch Święty prowadzi, realizuje i spełnią historię Jezusa Chrystusa i Jego Kościoła w łonie uniwersalnej historii doczesnej. Nie ma zbawienia bez Ducha Świętego, bo On właśnie „przejmuje od Syna dzieło odkupienia świata” (DeV 28), On „sam ma dalej prowadzić zbawcze dzieło, zakorzenione w ofierze Krzyża" (DeV 42) ${ }^{13}$.

\section{Gdy Duch Paraklet przyjdzie, „przekona świat o grzechu, o sprawiedliwości i o sądzie" (J 16, 8)}

Duch Święty, który wspólnie z Ojcem i Synem bierze udział w dziele stworzenia świata i człowieka, „zna od początku tajemnicę człowieka” (DeV 35). Ta tajemnica człowieka to nie tylko prawda o jego stworzeniu, ale także tajemnica jego odejścia od Boga - tajemnica jego grzeszności. Oznacza to, że będąc - jako zasada życia - immanentny w stosunku do człowieka i świata, którą to immanencję Boga w człowieku i świecie Jan Paweł II określił jako „kondescendencja Ducha” (DeV 55), Duch Święty natrafia na opór i sprzeciw ze strony człowieka, co sprawia, że do rzeczywistości Kościoła można odnieść pojęcie grzechu, niewierności czy pokusy. Kościól, będąc Oblubienicą, Ciałem Chrystusa, zjednoczony z Nim nierozerwalną więzią Przymierza, pozostaje równocześnie wspólnotą ludzi, którzy - wszyscy razem i każdy z osobna - są słabi i grzeszni. W tym aspekcie niezwykle płodne okazuje się zastosowanie dialektycznej prawdy o Kościele - Ludzie Bożym pielgrzymującym w czasie między Zesłaniem Ducha Świętego i Paruzją, między ,już a jeszcze nie”. Nie można jednak dopuścić, aby to ,jeszcze nie” odebrało temu ,już” całą zawartą o nim prawdę ${ }^{14}$. W tym kontekście należy odczytywać rolę Ducha Świętego w „przekonywaniu świata o grzechu, sprawiedliwości i sądzie" (J 16, 8) $)^{15}$. Żywa obecność Ducha Świętego, przeżywana przez chrześcijan, musi się zmierzyć z mocą zła, obecną w świecie i w człowieku' ${ }^{16}$.

Istotą tego przekonywania o grzechu jest wykazywanie zła, które się w tym grzechu zawiera. A ponieważ zła grzechu nie sposób dosięgnąć w całej jego bolesnej rzeczywistości, jeśli nie odniesie się jej do tajemnicy samego Boga, dlatego tylko Duch Święty, „który przenika głębokości Boże”, może do końca objawić człowiekowi „ponurą tajemnicę grzechu” (DeV 39).

13 Bartnik, „Duch Święty a hamartologia”, 167. Emfaza ta jest szczególnie istotna dla teologii zachodniej, dla której niekiedy odkupieńcza historia Jezusa jest kontynuowana w historii świata bez Ducha Świętego, często nawet bez Kościoła i sakramentów.

14 Congar, Kościót, jaki kocham, 33-35.

15 Dąbek, „Gdy Duch Paraklet przyjdzie”, 5-14.

16 Mroczkowski, „Duch, który przekonywa o grzechu”, 131-149. 
Odnosi się ono nie tylko do konkretnych grzechów ludzkich, lecz również do całej głębi tajemnicy człowieka noszącego w sobie to rozdarcie, które wyraża się w skłonności do grzechu. Prowadzi ono wprost do pytania o prawość sumienia: „Ewangeliczne «przekonywanie o grzechu» pod wpływem Ducha Prawdy nie może urzeczywistniać się w człowieku na innej drodze, jak tylko na drodze sumienia”. Tylko prawe sumienie, które nazywa po imieniu dobro i zło, może być gwarantem rozwiązania „w prawdzie tylu problemów moralnych, które narzucają się tak w życiu jednostek, jak i we współżyciu społecznym" (DeV 43).

Papież nazywa to przekonywanie o grzechu „zbawczym” (DeV 31). Duch Święty bowiem nie prowadzi człowieka jedynie do rozpoznania grzechu w sobie, ale jednocześnie skierowuje go do dobra, wskazując, że każdego grzechu może dosięgnąć zbawcza moc Boża (DeV 42). Nie chodzi więc jedynie o oskarżenie świata, ani tym bardziej o jego potępienie, bo przecież Chrystus przyszedł na świat nie po to, aby go potępić, ale po to, aby go zbawić (por. J 3,17; 12,47); „To przekonywanie o grzechu pozostaje w stałym odniesieniu do «sprawiedliwości» - czyli do ostatecznego zbawienia w Bogu" (DeV 28). Zbawczy charakter przekonywania o grzechu sprawia, że ma ono swoje fundamentalne odniesienie do dzieła zbawienia, jakiego Bóg Ojciec dokonał przez swojego Syna Jezusa Chrystusa. „W taki sposób «przekonywanie o grzechu» staje się równocześnie przekonywaniem o odpuszczeniu grzechów w mocy Ducha Świętego" (DeV 31).

Znakiem owego przekonywania jest Krzyż: świadek odrzucenia Boga, a jednocześnie świadek Bożego miłosierdzia i przebaczenia. Spojrzenie na grzech w relacji do Krzyża ukazuje go najpierw „w pełnym wymiarze misterium iniquitatis”, a więc w pełnej skali zła, jaka jest mu właściwa. Równocześnie jednak grzech „zostaje zidentyfikowany w pełnym zarazem wymiarze misterium pietatis" (DeV 32).

Tak więc człowiek grzeszny nie jest pozostawiony samemu sobie, lecz otrzymuje obietnicę zbawienia złączoną z darem przebaczenia grzechów i wezwaniem do nawrócenia. Stąd spośród tych dwu wymiarów przekonywania o grzechu ważniejsze jest odniesienie do misterium pietatis, czyli takiego ukazywania ludzkiego grzechu, aby człowiek był przekonany, że mocą dokonanego przez Chrystusa zbawienia może przezwyciężyć każdy grzech. Te dwa wymiary „przekonywania o grzechu” Jan Paweł II ujmuje w kategoriach tzw. "grzechu potępionego" i ,grzechu zbawionego", akcentując w ten sposób konieczność rozpatrywania grzechu w ramach ekonomii zbawienia. Zarówno jeden, jak i drugi rodzaj grzechu może być rozpoznany jedynie w relacji do Krzyża Chrystusowego. Człowiek „nie może być [o nich] «przekonany», jak tylko przez Ducha Świętego: Tego, który «przenika głębokości Boże»” (DeV 32).

Odczytanie opisanego stanu rzeczy na płaszczyźnie teologicznomoralnej wskazuje na grzech, który narusza pierwotną harmonię między człowiekiem a Bogiem, drugim człowiekiem, naturą i nim samym. Dotykamy tu prawdy, że "pomiędzy pierwszym początkiem a całymi dziejami człowieka - począwszy od pierworodnego upadku - zaległ grzech, który jest przeciwieństwem obecności Ducha Świętego w stworzeniu, nade wszystko zaś przeciwieństwem zbawczego udzielania się czło- 
wiekowi” (DeV 13). Grzech ten, który opanował ludzkie serca, przejawia się w człowieku jako wewnętrzne rozdarcie i zarazem źródło kolejnych konfliktów. Doświadcza on nieustannie, że w nim, jako istocie duchowo-cielesnej, istnieje pewne napięcie - niejako walka między dążeniami ducha i ciała - które znajduje następnie swoje przedłużenie na płaszczyźnie społecznej, dotykając także wspólnoty Kościoła.

Pomijając w tym miejscu analizę różnorodnych przejawów oporu i sprzeciwu wobec Ducha Świętego, charakterystycznych dla współczesnego świata, trzeba wskazać na kilka ważnych imperatywów moralnych z nimi wiązanych, które winny towarzyszyć chrześcijanom w ich podejściu do świata, zwłaszcza do istniejącego w nim zła. W pierwszej kolejności chodzi o podejście z całym realizmem do zła obecnego w człowieku i w świecie. W codziennych wyborach postawa realizmu będzie oznaczać najpierw odrzucenie fałszywego triumfalizmu i naiwnego optymizmu. Fałszywe pomniejszanie zagrożeń i lekceważenie dramatu zła nie przyczynia się w żadnej mierze do jego usunięcia. $Z$ drugiej strony konieczne jest równoczesne wyzbycie się jakiegoś fatalizmu w odniesieniu do zła i grzechu obecnego w człowieku i w świecie, odrzucenie przekonania, że człowiek nie może w żaden sposób wyzwolić się od zła, że jest na nie skazany.

Różnego rodzaju przejawy oporu, jak i sprzeciwu wobec Ducha Świętego, nie mogą być traktowane jako podstawa do przyjęcia biernej postawy wobec świata. Pawłowa antyteza ducha i ciała (Rz 7,12-25), znajdująca swoje przedłużenie w przeciwstawieniu życia i śmierci nie może być rozumiana jako deprecjacja ciała ludzkiego czy też doczesnego wymiaru życia człowieka wraz z jego środowiskiem, którym jest cały świat. Nastawienie to byłoby przejawem skrajnie dualistycznej wizji świata, w której niejako na tym samym poziomie stawia się zbawcze działanie Boga i działanie złego ducha, a także wyrazem braku nadziei chrześcijańskiej. Świat bowiem współczesny, w którym Duch Święty wciąż natrafia na sprzeciw i opór, jest przecież światem zbawionym, jest światem, który „oczekuje objawienia się synów Bożych” (Rz 8,19), oczekuje wyzwolenia z niewoli zepsucia, by uczestniczyć w wolności i chwale dzieci Bożych (por. Rz 8,20-21) ${ }^{17}$.

Świat - jako stworzenie Boże - nie może być także absolutyzowany, to znaczy nie może być przeciwstawiany Bogu ani oddzielany od Niego. Wówczas bowiem zwraca się on przeciwko człowiekowi i staje się dla niego zły. Takie pojmowanie świata pozwala zrozumieć chrześcijanom, wich zaangażowaniu w sprawy tego świata, i całemu Kościołowi, w jego posłannictwie w świecie, że nie można ignorować zła, które w tym świecie rzeczywiście istnieje. Powinni oni zachować krytyczny dystans do wszystkiego, co istnieje w tym świecie, zwłaszcza do istniejących struktur i instytucji życia ludzkiego, albowiem są one zawsze w jakiejś mierze obciążone piętnem grzechu $^{18}$.

17 Nagórny, „Duch Święty”, 98-99, 123.

18 Nagórny, „Duch Święty”, 110; Klauza, „Hamartologia”, 225-228; Bastianel, „Strutture”, 15-38. 
Realizm w opisywaniu dramatycznych przejawów zarówno oporu, jak i sprzeciwu przeciwko Duchowi Świętemu, nie może prowadzić także do ulegania pokusie pesymizmu i rezygnacji. Jak już wskazano, świat, w którym przyszło ludziom wierzącym przeżywać swoją wiarę i w którym Duch Święty natrafia na sprzeciw i opór, jest przecież światem zbawionym, który oczekuje objawienia się synów Bożych.

Tym znakiem nadziei pośród świata, a jednocześnie i znakiem sprzeciwu wobec zła i grzechu, winien właśnie stać się Kościół, który wypełniając swoje posłannictwo w świecie i wobec świata, czyni to za sprawą Ducha Świętego. Tylko Kościół jako wspólnota ludzi prowadzonych przez Ducha Świętego, poszukujący dróg jedności, może być skutecznym narzędziem w całym procesie przezwyciężania istniejącego w człowieku i w świecie oporu i sprzeciwu wobec Ducha Świętego.

Głosząc swoje orędzie o zbawieniu - które jest także orędziem o Duchu Świętym - Kościół czyni to w rzeczywistości przemijania nieba i ziemi. Doświadczenie to jednak nie oznacza - jak już powiedziano - lekceważenia doczesnego wymiaru życia ludzkiego i posłannictwa Kościoła w świecie, albowiem cała tajemnica Wcielenia, która dokonuje się za sprawą Ducha Świętego, „oznacza przyjęcie do jedności z Bogiem nie tylko ludzkiej natury, ale - w tej naturze - poniekąd wszystkiego, co jest "ciałem»: całej ludzkości, całego widzialnego, materialnego świata" (DeV 50). Dlatego też Kościół, czując się naprawdę złączony z całym rodzajem ludzkim i całą historią świata, nie może wyłączyć posłannictwa wobec świata poza nawias własnej misji.

\section{Profetyczno-krytyczna funkcja nauki społecznej Kościoła: doprowadzić do "całej prawdy" w życiu społecznym}

Immanentny konflikt Ducha Świętego i człowieka (DeV 55) wiąże się z prawdą, że został On posłany do człowieka wolnego, a zarazem do człowieka, który z racji grzechu może zafałszować swoją wolność i w wieloraki sposób jej nadużyć. W ten sposób człowiek może nie tylko „zasmucać” Ducha Świętego, ale i przeciwstawić się Jemu.

Duch Święty ma za zadanie doprowadzić człowieka do całej prawdy (por. J 16,12-13). Człowiek jednak może nie chcieć poznać i przyjąć całej prawdy, może zadowolić się jakąś prawdą cząstkową, a niekiedy nawet godzić się na prawdę pozorną. Wiąże się to ściśle $\mathrm{z}$ wiarą, albowiem to $\mathrm{w}$ wierze i przez wiarę dokonuje się doprowadzenie człowieka do „całej prawdy”. Wiara jest zaś dziełem Ducha Prawdy, który zapala światło wiary w sercu człowieka ${ }^{19}$. Człowiek jednak nie jest jakimś bezwolnym narzędziem tego działania, może powiedzieć Duchowi Świętemu „nie”, może Mu się sprzeciwić. W świetle tego działania Ducha Świętego, które jest doprowadzeniem do „całej prawdy”, wybrzmiewa z całą mocą, że grzech jest kłamstwem, odejściem od

19 Smentek, „Duch Prawdy”, 179-202. 
prawdy o Bogu i człowieku; jest swoistym aktem niewiary, albowiem u jego korzenia leży kłamstwo i radykalne odrzucenie Bożej prawdy (DeV 33$)^{20}$.

Tajemnica grzechu wyrasta więc z aktu woli człowieka sprzeciwiającego się zbawczej woli Boga. W tym akcie, zrodzonym wbrew prawdzie, na gruncie kłamstwa, człowiek postawił w stan oskarżenia i permanentnego podejrzenia stwórczą i zbawczą Miłość. Człowiek poszedł w ten sposób za „ojcem kłamstwa”, odrzucając Ojca życia i Ducha Prawdy (DeV 39). Ten konflikt z Duchem Świętym jako Duchem Prawdy Jan Paweł II uznaje za opowiedzenie się za „anty-Słowem” i za "przeciw-Prawdą”:

Zostaje bowiem zakłamana prawda o tym, kim jest człowiek, jakie są nieprzekraczalne granice jego bytu i jego wolności. Ta „przeciw-Prawda” jest możliwa dlatego, że równocześnie zostaje dogłębnie „zakłamana” prawda o tym, kim jest Bóg. Bóg-Stwórca zostaje postawiony w stan podejrzenia, głębiej jeszcze: w stan oskarżenia w świadomości stworzeń (DeV 37$)^{21}$.

Opór stawiany Duchowi Świętemu w pierwszej kolejności w wymiarze wewnętrznym i podmiotowym, a więc opór w sercu człowieka, znajduje swoje przedłużenie w zobiektywizowanym kształcie kultury i cywilizacji, co we współczesnej teologii znalazło wyraz w koncepcji „grzechu społecznego” i „struktur grzechu”, które są niczym innym jak społecznym wyrazem tego zakłamania i odrzucenia prawdy, które dokonało się w sercu człowieka przez poddanie się „ojcu kłamstwa”22. Kłamstwo o Bogu i człowieku, przybierając charakter systemu filozoficznego, określonej ideologii, czy też będąc praktycznym wyrazem życia w określonym środowisku społeczno-kulturowym, wyrastając z grzechu konkretnych ludzi, jednocześnie staje się jednym z istotnych źródeł współczesnego sprzeciwu i oporu przeciwko Duchowi Świętemu w sumieniach wielu ludzi ${ }^{23}$.

To istnienie zła w wymiarze życia społecznego oznacza, że Duch Święty, wykonując swoją misję w świecie, będzie wykazywał także winę „świata” w odrzuceniu Chrystusa. Świat bowiem, poddając się działaniu szatana, stał się współcześnie wyraźnym miejscem sprzeciwu i oporu wobec działania Ducha Świętego. Taki obraz świata wyłania się zwłaszcza z teologii Janowej, kojarzony jest z tym, co doczesne, złe i zniszczalne w człowieku, nade wszystko poprzez jego odniesienie do grzechu. W rozumieniu św. Jana ten świat jest światem ludzi obojętnych lub wrogich wobec Jezusa i Jego uczniów (por. J 7,7; 16,20.33; 1 J 3,1), nie ma Ducha Świętego (por. J 14,17), lecz posiada własnego ducha (por. 1 Kor 2,12). Świat związany z grzechem jest miejscem działania szatana (por. J 12,31), i choć stworzony przez Boga, może się Jemu sprzeniewierzyćc ${ }^{24}$.

20 Nagórny, „Duch Święty”, 104.

21 Bartnik, „Duch Święty a hamartologia”, 169-170.

22 Jan Paweł II, Reconciliatio et paenitentia, nr 16.

23 Nagórny, „Duch Święty”, 109-123.

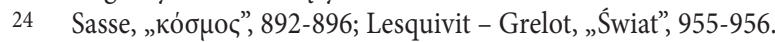


Takie ujęcie świata nie oznacza jednak jego odrzucenia. Pomimo grzechu i zła pozostaje on nadal znakiem Bożej Opatrzności i jest ukierunkowany na Boże dzieło zbawienia. Nakazuje to jednak chrześcijanom przyjąć postawę czujności i roztropności. Nie mogą oni absolutyzować świata, lecz powinni rozeznawać jego ambiwalentny charakter, mając świadomość, że przeciwstawiany Bogu lub oddzielany od Niego i naznaczony piętnem grzechu, może zwrócić się ostatecznie przeciw człowiekowi ${ }^{25}$.

Odpowiedzią prowadzonego przez Ducha Świętego Kościoła na zaistniałą sytuację jest ukazywanie dróg prawdy, bowiem tylko na jej fundamencie można budować społeczeństwo prawdziwie wolne, zdolne rozwiązywać wszelkie problemy, a nade wszystko zdolne przezwyciężyć różne formy totalitaryzmu, który „rodzi się z negacji obiektywnej prawdy"26. Totalitaryzm jako fundamentalne zaprzeczenie prawdy i wolności jest więc też fundamentalnym znakiem oporu i sprzeciwu człowieka, który taki system tworzy, wobec Ducha Świętego jako Ducha prawdy i wolności.

W tym kontekście szczególne zadanie przezwyciężania zła w życiu społecznym przypada nauce społecznej Kościoła. Pomijając w tym miejscu dyskusje dotyczące jej statusu metodologicznego, na płaszczyźnie doktrynalnej jest ono zdefiniowane jako owoc refleksji nad złożoną rzeczywistością ludzkiej egzystencji w społeczeństwie, przeprowadzonej w świetle wiary i tradycji kościelnej pod kątem poszanowania godności osobowej człowieka, odczytanej zarówno w duchu personalizmu, jak i na płaszczyźnie nadprzyrodzonej ${ }^{27}$. Poprzez swoją naukę społeczną Kościół proponuje i objawia światu prawdziwy i pełny obraz człowieka jako kryterium oceny wszelkich form i struktur życia społecznego ${ }^{28}$. „Kościół jest jedynym historycznym miejscem, które gwarantuje prawdziwość teoretycznego poznania i praktycznej realizacji objawionej tożsamości człowieka”. Innymi słowy „poza Kościołem (extra Ecclesiam) nie ma w ludzkim świecie innego miejsca umożliwiającego aktualizację historycznej pełni tego poznawczego przeżywania"29.

Pełna prawda o człowieku stanowi podstawę nie tylko społecznej doktryny Kościoła, ale także jego posłannictwa względem świata. Kwestia ta jest tak istotna, ponieważ soborowe przeświadczenie, że ośrodkiem życia społecznego we wszystkich jego obszarach jest człowiek - co oznacza przyznanie mu centralnego miejsca i roli w strukturach instytucji społecznych - nie wyczerpuje jeszcze omawianej problematyki. Kościół, świadomy możliwości różnych redukcji czy zafałszowań, „ukazuje równocześnie sens jego własnej egzystencji, to znaczy najgłębszą prawdę o człowieku"30.

Taką samą rolę pełni Kościól, gdy - prowadzony przez Ducha Świętego - demaskuje i piętnuje grzech społeczny, niesprawiedliwość, gdy wzywa do nawrócenia,

\footnotetext{
25 Gocko, Kościół obecny w świecie, 177-178.

26 Jan Paweł II, Centesimus annus, nr 44.

27 Jan Paweł II, Sollicitudo rei socialis, nr 41.

28 Jan Paweł II, Centesimus annus, nr 55.

29 Cuda, Praktyczno-społeczne kryterium wiarygodności, 200-201.

30 Sobór Watykański II, Gaudium et spes, nr 41.
} 
pojednania i realizowania ideału miłości, solidarności i pokoju, gdy - zwracając się do wszystkich ludzi dobrej woli - staje się rzecznikiem wartości uniwersalnych, gdy - biorąc pod uwagę przesłanie Ewangelii o człowieku i świecie - dokonuje oceny moralnej istniejących systemów i struktur społecznych.

To szczególne ukierunkowanie na człowieka i jego sprawy znajduje swoje uzasadnienie w ukazanym w pierwszej części analiz inkarnacyjnym i pneumatologicznym charakterze obecności Kościoła w świecie. Wcielenie, a więc wejście Boga w czas i historię oraz przyjęcie ludzkiej natury przez Słowo, które realizuje, prowadzi i spełnia Duch Święty w łonie uniwersalnej historii doczesnej, dokonało się po to, aby podnieść wszystko, co istnieje w człowieku, ponieważ cały człowiek został odkupiony i przebóstwiony ${ }^{31}$. Ukierunkowanie to wyraża się zwłaszcza w bezkompromisowym zaangażowaniu Kościoła w obronę godności człowieka i jego praw. Pełniąc taką misję względem człowieka i społeczności ludzkiej, Kościół - poddany Duchowi Świętemu - odnajduje się jako realizujący w historii zbawczą misję Chrystusa. Stąd wypływa ostatecznie profetyczno-krytyczny wymiar jego posłannictwa, a będąc w służbie królestwa Bożego, staje się równocześnie wymiarem zbawczym.

Analiza dokumentów Kościoła wskazuje, że jego nauka społeczna zawiera oceny wielu konkretnych sytuacji, struktur, systemów społecznych i ideologii. Są to zawsze oceny konkretnej rzeczywistości w oparciu o stałe zasady. Jest to równocześnie zgodne ze współczesną myślą teologiczną, która swoją misję upatruje nie tyle w wyłożeniu zasad danego systemu społecznego, gospodarczego czy politycznego, ale raczej w nauczaniu na temat wartości i zasad moralnych, które winny być uwzględniane przy jego tworzeniu lub ocenie ${ }^{32}$. W tym kontekście encyklika Sollicitudo rei socialis mówi o potrójnym paradygmacie: o zasadach refleksji, kryteriach ocen i wytycznych działania (nr 8). Oznacza to, że pierwszym punktem odniesienia jest „ów chrześcijański zrąb prawdy, który można nazwać odwiecznym"333, czyli wartości podstawowe, do których należy przede wszystkim godność osoby ludzkiej wraz z osobową wolnością człowieka.

31 Congar, „Implicazioni cristologiche”, 97-110; Kreck, Grundfragen der Ekklesiologie, 55-100.

32 Zwraca na to uwage m.in. Luigi Lorenzetti: „Il pensiero teologico contemporaneo riconosche che la missione della chiesa non è quella di insegnare dei sistemi, bensì dei valori” („Rapporto dialettico”, 612). Z kolei Karl-Heinz Peschke tę samą prawdę ujmuje w następujący sposób: „Die Kompetenz der Kirche liegt nicht auf dem Gebiet der praktischen Machbarkeit bestimmter wirtschaftlicher Strategien, sondern auf dem ihrer Kompatibilität mit den moralischen Werten und Zielen der Menschheit" (Wirtschaft aus christlicher Sicht, 23). Jan Paweł II, Laborem exercens, nr 3. 


\section{Zakończenie}

Kościół poprzez swoją naukę społeczną wypełnia profetyczno-krytyczne i zarazem humanizacyjne posłannictwo w życiu publicznym, mając świadomość, że jeśli działa w służbie wyzwolenia człowieka $\mathrm{z}$ różnorakich zniewoleń czy alienacji społecznych, gospodarczych czy politycznych, a więc tych wszystkich form zła w życiu społecznym, które stawiają zewnętrzny opór przeciwko Duchowi Świętemu, staje się znakiem obecności królestwa Bożego.

Celem tego chrześcijańskiego rozeznania, rozumianego jako poszukiwanie prawdy i ocena prawdziwości sądów, jest badanie istotnych przyczyn zła społecznego, owych znamion misterium iniquitatis, szczególnie niesprawiedliwości, a zarazem korzystanie ze sprawdzonego, nieskażonego wpływem ideologii, dorobku nauki o człowieku. Innymi słowy,

chodzi tu o sformułowanie obiektywnej oceny rzeczywistości społecznej w świetle trwałych zasad oraz wskazanie konkretnych, właściwych rozwiązań - możliwych i dostępnych w danych okolicznościach - które usuną niesprawiedliwość i będą sprzyjać koniecznym przemianom politycznym, ekonomicznym i kulturowym ${ }^{34}$.

Właściwe odczytanie pełnej prawdy o człowieku, zwłaszcza w dobie agnostycyzmu i sceptycznego relatywizmu - co Kościół postrzega jako swoje szczególne zadanie - staje się niezwykle istotne dla całego życia społecznego. Jeśli bowiem zostanie zafałszowana prawda o człowieku, tym samym zostanie zniekształcona hierarchia wartości, odrzucony obiektywny porządek moralny i zanegowane istnienie prawdy obiektywnej, poprzez której posłuszeństwo człowiek zdobywa swoją tożsamość.

Stosunek Kościoła do prawdy był niejednokrotnie przyczyną oskarżania go o zapędy totalitarne i postrzegania chrześcijaństwa bądź to podobnie do wielkich ideologii ubiegłego stulecia, które doprowadziły do powstania systemów totalitarnych, bądź to podobnie do niektórych współczesnych nurtów fanatyzmu religijnego, zwłaszcza islamskiego. W odpowiedzi na te zarzuty Jan Paweł II stwierdzał, że

Kościół nie zamyka bynajmniej oczu na niebezpieczeństwo fanatyzmu czy fundamentalizmu tych ludzi, którzy w imię ideologii uważającej się za naukową albo religijną czują się uprawnieni do narzucania innym własnej koncepcji prawdy i dobra. Prawda chrześcijańska do tej kategorii nie należy. Nie będąc ideologią, wiara chrześcijańska nie sądzi, by mogła ująć w sztywny schemat tak bardzo różnorodną rzeczywistość społeczno-polityczną i uznaje, że życie ludzkie w historii realizuje się na różne sposoby, które bynajmniej nie

Kongregacja ds. Wychowania Katolickiego, Wskazania, nr 8. 
są doskonałe. Tak więc metodą Kościoła jest poszanowanie wolności przy niezmiennym uznawaniu transcendentnej godności osoby ludzkiej ${ }^{35}$.

Należy zauważyć, że niejednokrotnie to właśnie państwo oczekuje od Kościoła wzmocnienia podstaw aksjologicznych i dostarczenia wyraźnych punktów orientacyjnych niezbędnych dla porządku prawnego. Jest to widoczne zwłaszcza na tle współczesnych procesów indywidualizacyjnych, rozkładu więzi społecznych, przesadnej roszczeniowości jednostek. W tych okolicznościach nie brak głosów płynących z kręgów politycznych, aby religia i instytucje kościelne pełniły role gwarancyjne dla wartości, które demokracja zakłada i do których się odwołuje, nie będąc w stanie sama ich generować. Przykładem obszaru, który domaga się odnowy, jest etos praw człowieka. Wydaje się, że to właśnie Kościoły chrześcijańskie i inne wspólnoty religijne powinny wnosić do wspólnego wszystkim ludziom etosu praw człowieka poczucie obowiązku i odpowiedzialności. Funkcja krytyczna Kościoła wobec świata, odczytana w niniejszym studium przez pryzmat przekonywania przez Ducha Świętego o grzechu, pozwala mu także zachować konieczny dystans względem świata, co prowadzi w konsekwencji do bycia znakiem sprzeciwu, zwłaszcza wobec wszelkich redukcjonizmów i alienacji ${ }^{36}$. Swoje ostateczne uzasadnienie znajduje ona w wymownym sformułowaniu Soboru Watykańskiego II, iż jest on „znakiem i obroną transcendencji osoby ludzkiej" ${ }^{37}$.

\section{Bibliografia}

Bartnik, C., „Duch Święty a hamartologia”, Jan Paweł II. Dominum et Vivificantem. Tekst i komentarze (red. A.L. Szafrański) (Lublin: RW KUL 1994) 161-171.

Bastianel, S., „Strutture di peccato. Riflessione teologico-morale”, Strutture di peccato. Una sfida teologica e pastorale (red. B. Sorge) (Casale Monferrato: Piemme 1989) 15-38.

Chenu, M.-D., La Parole de Dieu. II. L'Évangile dans le temps (Paris: Cerf 1964).

Chenu, M.-D., Un théologien en liberté. Jacques Duquesne interroge le Père Chenu (Paris: Centurion 1975).

Congar, Y., Duch człowieka, Duch Boga (Warszawa: Wydawnictwo Księży Marianów 1996).

Congar, Y., „Implicazioni cristologiche e pneumatologiche dell'ecclesiologia del Vaticano II”, Cristianesimo nella storia 2 (1981) 97-110.

Congar, Y., Kościót, jaki kocham (Kraków: Kairos 1997).

Congar, Y., „Les implications christologiques et pneumatologiques de l'ecclésiologie de Vatican II", Les Églises après Vatican II: dynamisme et prospective. Actes du Colloque International

35 Jan Paweł II, Centessimus annus, nr 46.

36 Por. Gocko, Nauka społeczna Kościoła, 290-307.

37 Sobór Watykański II, Gaudium et spes, nr 46. 
de Bologne, 1980 (red. G. Alberigo) (Théologie Historique 61; Paris: Beauchesne 1981) 117-130.

Congar, Y.: Wierzę w Ducha Świętego (Warszawa: Wydawnictwo Księży Marianów 1995-1996) I-III.

Cuda, J., Praktyczno-społeczne kryterium wiarygodności objawionego sensu historii. Analityczno-syntetyczne studium inspirowane paradygmatem nowej teologii politycznej (Katowice: Księgarnia Św. Jacka 1999).

Czaja, A., Credo in Spiritum Vivificantem. Pneumatologiczna interpretacja Kościoła jako komunii w posoborowej teologii niemieckiej (Lublin: Wydawnictwo KUL 2003).

Dąbek, T.M., „Gdy Duch Paraklet przyjdzie, «przekona świat o grzechu, o sprawiedliwości i o sądzie»", Ruch Biblijny i Liturgiczny 59/1 (2006) 5-14.

Gocko, J., „Historyczność jako wewnętrzna zasada myślenia teologicznego”, In Persona Christi. Księga na 80-lecie księdza profesora Czesława S. Bartnika (red. K. Góźdź) (Lublin: Wydawnictwo KUL 2009) II, 377-384.

Gocko, J., Kościół obecny w świecie - posłany do świata. Teologiczno-społeczne aspekty posłannictwa Kościoła w świecie po Soborze Watykańskim II (Lublin: Wydawnictwo KUL 2003).

Gocko, J., Nauka społeczna Kościoła w poszukiwaniu własnej tożsamości (Warszawa: Towarzystwo Naukowe Franciszka Salezego 2013).

Jan Paweł II, Adhortacja apostolska Reconciliatio et paenitentia (1984).

Jan Paweł II, Encyklika Centesimus annus (1991).

Jan Paweł II, Encyklika Dominum et Vivificantem (1986).

Jan Paweł II, Encyklika Laborem exercens (1981).

Jan Paweł II, Encyklika Sollicitudo rei socialis (1987).

Klauza, K., „Hamartologia społeczna w Sollicitudo rei socialis”, Historia i logos (red. K. Macheta - K. Góźdź - M. Kowalczyk) (Lublin: RW KUL 1991) 222-231.

Kongregacja ds. Wychowania Katolickiego, Wskazania dotyczace studiów i nauczania doktryny społecznej Kościoła w ramach formacji kapłańskiej (1988).

Kreck, W., Grundfragen der Ekklesiologie (München: Kaiser 1981).

Krzemiński, K., „Encyklika Dominum et Vivificantem Jana Pawła II - próba teologicznej refleksji”, Pneuma Hagion. W dwudziestolecie encykliki Jana Pawła II o Duchu Świętym w życiu Kościoła $i$ świata (red. T. Siuda) (Poznań: UAM Wydział Teologiczny 2007) 129-148.

Lesquivit, C., Grelot P., „Świat”, Słownik teologii biblijnej (red. X. Léon-Dufour) (Poznań: Pallottinum 1990) 955-956.

Lorenzetti, L., „Rapporto dialettico tra valori sociali e sistemi socio-economici”, Rivista di Teologia Morale 13 (1981) 611-615.

Łukaszyk, R., „Teologiczne spojrzenie na Kościół”, Katecheta 8/1 (1964) 5-10.

Mroczkowski, I.: „Duch, który przekonywa o grzechu”, Duch Święty w posłudze Kościoła wobec świata (red. J. Nagórny - J. Gocko). (Lublin: Wydawnictwo Salezjańskie 1999) 131-149.

Nagórny, J.: „Duch Święty «natrafia na opór i sprzeciw» w dzisiejszym świecie”, Duch Święty w posłudze Kościoła wobec świata (red. J. Nagórny - J. Gocko) (Lublin: Wydawnictwo Salezjańskie 1999) 97-130.

Peschke, K.H., Wirtschaft aus christlicher Sicht (Trier: Paulinus 1992).

Pius XII, Encyklika Mystici Corporis (1943). 


\section{JERZY GOCKO}

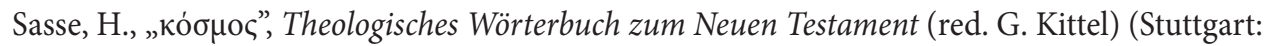
Kohlhammer 1938) III, 892-896.

Smentek, I., „Duch Prawdy”, Duch Święty (Scripturae Lumen 8, Tarnów: Biblos 2016) 179-202.

Sobór Watykański II, Konstytucja duszpasterska o Kościele w świecie współczesnym Gaudium et spes (1965).

Szwarc, U., „Duch Święty jako życiodajna zasada (fundament biblijny)”, Duch Święty w posłudze Kościoła wobec świata (red. J. Nagórny - J. Gocko) (Lublin: Wydawnictwo Salezjańskie 1999) 31-49.

Świątek, A., „Pneumatologiczna interpretacja obecności Chrystusa w Kościele i świecie według encykliki Jana Pawła II Dominum et Vivificantem”, Duch Święty. Kościół. Człowiek. I. Kościół w mocy Ducha Świętego (red. S.C. Napiórkowski) (Lublin: Wydawnictwo KUL 2011) 1063-1087. 